\title{
Land-related conflicts in Sub-Saharan Africa
}

\author{
Urmilla Bob*
}

\section{Abstract}

Sub-Saharan Africa has a history of land dispossession and contestation which have resulted in various types of inequalities and a skewed distribution of land resources. Land in Sub-Saharan Africa has been subject to conflict, conquest, expropriation and exploitation thus resulting in the many discrepancies that exist today. This has greatly influenced the socio-economic and political positions of different groups of people. This situation has resulted in numerous land conflicts, and in most Sub-Saharan countries the land question and past inequalities remain unresolved. This article shows that there are various types of land conflicts in Sub-Saharan Africa. Furthermore, land conflicts are generally influenced by a range of complex and interrelated factors. Specifically, aspects relating to poverty and inequality as well as land reformation processes are relevant given that contestations over land resources are most noticeable among the poor. Additionally, land conflicts are intensifying and becoming more widespread. The article also discusses key aspects that need to be considered when managing land conflicts. It is important to note that this article draws heavily on a South African perspective and is not an exhaustive review of the range of land-related conflicts on a diverse continent where significant variations exist. The focus is on highlighting key aspects and identifying commonalities.

* Prof Urmilla Bob is Associate Professor in the Discipline of Geography, School of Environmental Sciences at the University of KwaZulu-Natal, Durban. 


\section{Urmilla Bob}

\section{Introduction}

Land and related resources such as water and biodiversity are vital in marginalised communities since they offer diversified livelihood opportunities and alternatives. Land also provides a sense of security in contexts where formal employment opportunities and access to resources are limited. Land resources continue to have major historical, cultural and spiritual significance. As a result, land has been a source of conflict and contestation. Given its importance, access to and availability of land resources are critical to ensuring real and longlasting improvement in social, economic and political well-being, especially in vulnerable societies that are prone to instability and conflicts. Specifically, the amount and type of land in Sub-Saharan Africa available to households and communities are critical to food production and stability. Odgaard (2006:5), focusing on Tanzania, states:

The vital importance of land issues to social and economic development in Africa is unquestionable. The fact that land is becoming an increasingly scarce resource in many parts of the continent, and also a more and more conflict ridden resource, has implied that issues related to land rights and land conflicts now range high on the policy agendas both in African countries and among international donors.

This article examines land conflict issues in Sub-Saharan Africa in relation to the following thematic concerns: access to and control of land, key types of land conflicts discernible, and managing land conflicts.

\section{Access to and control of land}

There are varying degrees of land tenure in Africa, the most important of which are freehold/private titles, communal/traditional systems, public land, and squatting. Furthermore, various social dimensions (class, gender, religion, ethnicity) affect access to and ownership of land. Kagwanji (2009:4) asserts that across eastern Africa (specifically Kenya, Uganda, Tanzania and Rwanda) the question of the use and ownership of, and access to increasingly scarce land and related resources has been at the centre of festering conflicts between ethnic 


\section{Land-related conflicts in Sub-Saharan Africa}

groups in the region. At the community, household and individual levels, a range of factors influence who accesses and controls land resources. These relate to one's bargaining position which influences the level of success or failure in acquiring land. The external factors are broader economic and political forces, quantity and quality of land available, and the local economy and culture. These largely influence market prices and the amount and quality of land available. The internal factors are demographic aspects (such as gender, age, household status and lineage), economic status and social networks. These factors together with local culture can deny rights to certain groups, such as women and generally define who will benefit and be prioritised in terms of accessing land.

Ownership and control of land and related resources are often associated with influence in decision making and power to affect outcomes. Hutchison et al. (1991, cited in Rugege et al. 2007:27) illustrate that ownership, like all real rights, consists primarily of a relationship between a legal subject and a thing or legal object, encompassing complete and absolute control over the thing concerned as well as possible rights and capacities over it. They further assert that land tenure is a key factor in any economy since it confers property rights and defines access to and control over land assets, including natural resources that exist in or on the land. Additionally, it confers rights in relation to the manner in which people own, occupy and transact land. This also entails decisions pertaining to residential and business development, agricultural production and mining, and the use of other natural resources.

Issues of access and distribution are important in the context of land and people's power relationships with it. Viljoen's (2006:2) differentiation between poverty and inequality in the South African context is worth noting: poverty is characterised by the inability of individuals, households or communities to command sufficient resources to satisfy a socially acceptable minimum standard of living, while inequality refers to a state of social organisation in which access to resources and opportunities is unevenly apportioned. Bob et al. (2008:28) state that inequality is often a consequence of political, economic and social processes that concentrate resources in certain hands at the expense of others. In Sub-Saharan Africa the vast majority of the black population have limited access to land ownership and related natural resources, resulting in high levels 


\section{Urmilla Bob}

of vulnerability and resultant conflicts over land (Bogale et al. 2006; Rugege et al. 2007). Huggins et al. (2005:1) indicate that several studies 'demonstrate that changes in land use and land access have been significant factors in a number of high-intensity conflicts in Africa', but warn that they are not always the 'root causes'. Land control and use is a highly complex and contested issue amongst various stakeholders - including white/large-scale farmers, local communities, traditional authorities and democratically elected local institutions, each with often differing interests.

Another aspect to consider is increased globalisation. Shultz (2000, cited in Bob and Moodley 2003:359) argues that one consequence of globalisation is a decrease in international trade restrictions which is likely to influence the value of and market conditions for land and related resource products. The commoditisation of nature and privatisation of land is increasing worldwide. Furthermore, the trade in natural resources is also likely to increase. Bob and Moodley (2003:359) indicate that the commoditisation of land and natural resources in South Africa is often accompanied by a significant gap between local and global valuation of nature which is most discernable where economic differences are acute. Heightened conflicts over the use, control and ownership of land resources are also likely to occur in these contexts. Additionally, globalisation results in changes in land ownership patterns. This is likely to weaken autonomy and lead to vulnerable groups being exploited. This is also linked to the exploitation of local communities and is most discernible in relation to contestations over mining rights and harvesting of sought after plants for medicinal purposes. These contestations are worsened when rights are vested in the hands of multinational companies. Conflicts can also arise between local communities and governments who collude with these multinational companies.

\section{Key types of land conflicts in Sub-Saharan Africa}

Wehrmann (2006:2) states that a useful way to classify land conflicts is that offered by conflict research which examines conflicts according to the social level at which a conflict takes place: inner-personal, interpersonal, inner-societal and inter-societal/international. While the inner-personal is not relevant to land conflicts, the rest are discernible in the African context. Kinsey (2004:1669) 


\section{Land-related conflicts in Sub-Saharan Africa}

specifically uses the Zimbabwean experience to show the failures of resettlement programmes and the political motivations for land occupations (and resultant conflicts), and highlights the interlocking relationships among property, poverty and conflicts.

Reuveny (2007:656) cites several examples of land conflicts that resulted in environmental migration. For example in Africa, 600000 people moved from central/northern Ethiopia to the southwest/west regions because of drought and famine which resulted in nomad-farmer conflicts over land. During the early 1990s in Rwanda 1,7 million people moved from the central regions and rural south to northern Rwanda and Zaire as a result of ethnic conflicts and genocide which were exacerbated by land and water scarcity and degradation. Declining access to land, or rather to the returns from human uses of land, is seen as a key process that causes livelihood contraction and hence increases the risk that people will join armed groups (De Soysa et al. 1999, cited in Barnett and Adger 2007:644).

Several potential areas of land conflict within and between rural 'communities', and between rural people and state institutions exist. Types of post-apartheid rural land-based conflicts cited in the literature that are likely in communal areas of KwaZulu-Natal, South Africa, are listed below as illustrative examples relevant to Sub-Saharan Africa more generally (Carton 2000; Cousins and Hornby 2002; Cross and Friedman 1997; KZN Provincial Team 2002; Majeke 2005; Van der Waal 2004):

- Conflict between households, neighbourhoods and neighbouring 'communities' over land rights and boundaries.

- Conflict between traditional and 'non-traditional' local organisations in land management and dispute resolution.

- Inheritance-related conflict among family members.

- Conflict between 'newcomer' households and long standing residents.

- Conflict arising from household mobility.

- Generational conflict over land use and appropriation of benefits. 


\section{Urmilla Bob}

- Conflict between interest groups over appropriate land purposes.

- Distribution of benefits from land development projects.

- Escalating levels of crime and violence undermining both land rights and land management practices.

- Gender conflict over land access, land use and appropriation of benefits.

These are also noticeable in other land conflict studies which focus on Africa. For example, similar trends were found in Swaziland where Mkhabela (2006:58) identified the following potential sources of land conflicts: inequitable access to land and gender bias, overpopulation on Swazi nation land, land degradation, tenure insecurity, farm squatting and land scarcity, speculative trends in the land market, slow socio-cultural changes and lack of control due to non-existence of land rights. Bogale et al. (2006:134) examine the negative consequences of scarcity-induced land-related conflicts in Ethiopia which has resulted in high levels of household vulnerability. They observed that the absence of clearly defined property rights and management plans have led to the over-exploitation of the hillsides, leading to perpetuation of poverty and food insecurity.

Andrew (2003:117) argues that small-scale mining found in remote areas of developing countries routinely generates land use conflicts (occasionally involving armed conflicts), usually with large mining companies, which have significant adverse impacts on the natural environment and local populations. Hilson (2002:149) examines the impacts of land use disputes (linked to competition over land plots) between small- and large-scale miners in Ghana. In most cases these intense conflicts have also involved regional governmental officers and security forces.

Theron (2009:4) and Van Leeuwen (2009:1) highlight land-related conflicts in post-conflict environments, showing how in Burundi returnees (former refugees and displaced people) face considerable challenges in reclaiming and securing their land rights. Theron (2009:5) argues that if a large number of returnees are not able to reclaim their land and other properties, their frustrations could lead to violent actions'. Furthermore, Van Leeuwen (2009:7) warns that land disputes in Burundi need to be framed beyond 'returnee-related conflicts' if interventions 


\section{Land-related conflicts in Sub-Saharan Africa}

and peace-building efforts are to have long-term success. He asserts that disputes were related to a range of factors that also need to be understood such as the limited size of family property, patriarchal customary inheritance practices, cultural values attached to property and manipulations by state representatives. Andre and Platteau (1998, cited in Deininger and Castagnini 2006:324) assert that in Rwanda extreme land scarcity coincided with accumulation of land by individuals with access to non-agricultural incomes, which led to land conflict as one of the principal reasons for the outbreak of the civil war in 1994. Campbell et al. (2000:337) show that the land use conflicts in the south-eastern Kajiado district, Kenya, reflect the ongoing conflicts over access to scarce land and water resources between herding, farming and wildlife. Deininger and Castagnini (2006:321) indicate that ineffective land policies in Uganda have increased the frequency of land conflicts and reduced productivity levels.

The above discussion briefly summarises some of the key land conflicts in Sub-Saharan Africa, highlighting pertinent examples. Furthermore, Odgaard's (2006:25) observations in relation to Tanzania that conflicts have changed in nature and have been growing and becoming more complex, violent and involving larger numbers of people are relevant in most Sub-Saharan countries. Several of the conflicts identified are also linked to land reform processes, which are discussed next.

\section{Land reform and conflicts}

Land reform has been undertaken in almost all countries in Sub-Saharan Africa (Peters 2004:275) and this has particularly been a source of numerous conflicts.

To the extent that land policies reinforce the tendency of greater land scarcity to amplify pre-existing gender, ethnic, or wealth inequalities with respect to land access, they can contribute to a downward spiral of conflict, resource degradation, and social strife with potentially far-reaching implications for natural resource conservation and agricultural productivity (Deininger and Castagnini 2006:325). 


\section{Urmilla Bob}

Unravelling Africa's racially skewed land holding pattern is one of the most sensitive and complex issues facing governments on the continent. Land reform in Africa is generally undertaken to address political, social and economic imperatives and is deemed to be central to addressing past injustices in land access and allocation as well as contributing to local and national security. Land reform is viewed as one of the key means for positively changing people's lives. Land reform can take various forms including: the allocation of land itself, compensation, subsidies, laws that protect the land rights of previously disadvantaged groups or a combination of mechanisms. A major challenge facing land reform policy-makers and implementers is how to balance often conflicting social, economic and political land reform imperatives. This and the multiple demands and high number of potential beneficiaries have resulted in a range of land conflicts linked to land reform processes.

Land reform programmes identify specific beneficiaries that are to be targeted in particular projects. The targeting of specific groups is partly a result of governments taking into consideration that there are specific priority groups and the fact that there are limited resources which have to be effectively and efficiently utilised. This often results in conflicts as some people feel that they are disadvantaged and do not benefit from the land reform processes. Also, Huggins et al (2005:1) state that the actual or promised redistribution of land from weaker to stronger parties can fuel and prolong conflicts, as seen in Burundi, Rwanda and the Democratic Republic of the Congo. Additionally, several conflicts arise when the land that is allocated is deemed to be either inappropriate or inadequate. There are several resettlement failures associated with land reform throughout the continent which have resulted in conflicts and, as is the case in Zimbabwe, undermined national security (Kinsey 2004). Furthermore, market-led land reform projects (the approach often adopted in African countries) usually result in the wealthier segments of society benefiting.

The issue of the role of local government and traditional authorities in relation to land control and use in rural communities is highly contested (Deininger and Castagnini 2006; Mkhabela 2006). Deininger and Castagnini (2006:324) state that in much of Africa, formal institutions for land administration were often superimposed on traditional structures without clear delineation of 


\section{Land-related conflicts in Sub-Saharan Africa}

responsibilities and competencies, implying that they tend to lack both outreach and social legitimacy'. There is particularly uncertainty and lack of clarity about the role of traditional authorities in land reform programmes. Specifically, the role of traditional leaders in relation to administration and control of communal lands has been questioned. For example, Peters (2004:269) indicates that in Sub-Saharan Africa the image of negotiable and adaptive customary systems of landholding and land use is flawed; instead exclusions, deepening social divisions and class formation are intensifying land conflicts. In the case of South Africa, there is contestation between traditional institutions and democratically elected local government structures to allocate and manage land. This has in some instances resulted in outright conflicts in certain localities, de-stabilising communities and impeding prospects for peace and development.

Rugege et al. (2007:31) assert that the major problems faced by land management under traditional systems in South Africa are corruption, contradiction of traditional systems with modernity, selling or controlling of land for personal profit and benefits, and discriminatory practices. They indicate that the latter includes discrimination against women and a move towards commercial practices and accumulation. Furthermore, commercial agriculture results in the emergence of a new class who are encouraged to accumulate wealth and land. This, Rugege et al. (2007:32) indicate, can often result in an increase of the landless as wealthier segments of farmers buy out those who can no longer sustain production and survival given competition.

Another aspect that is important to consider is women's land rights and violence. Under most traditional systems land is not allocated to women but to men. Cross and Friedman (1997) assert that the gendered nature of land relations in some instances leads to violence against women. They provide an illustrative example from a study conducted by the Border Rural Committee in South Africa to show how land-induced violence has gender implications. Specifically, the frustration of young men unable to fulfil customary expectations by attaining land and a homestead has contributed to abuse of women from the 1940s. Cross and Friedman (1997) assert that studies indicate that in addition to leading to violence, the pattern of African men being unable to attain land rights as a result of artificial land shortages created by apartheid in South Africa 


\section{Urmilla Bob}

for most Africans, also contributes to declining rates of marriage, increased divorce and to male desertion of women and children. Carton (2000) warns that these forms of gender abuse should not be overlooked as a potentially dangerous and unforeseen area of conflict. In research undertaken by the author in KwaZulu-Natal, a telling example illustrating the gendered nature of land conflicts emerged during the colonial period. One woman interviewed recalled that under the amakhosi (chieftaincy) system when a husband died men in the community took the widow's field. When she went to the induna (headman) to settle the dispute he did nothing about it. Her family members from another community came to challenge the men and violence erupted.

The inability of governments to deliver on restitution claims has other unpleasant consequences. In many cases claimants lose faith in the entire process and see land invasions (which often have detrimental impacts on the environment) as the only option to speed up the process and get government attention. In Sub-Saharan Africa, there is yet another group of stakeholders that need to be considered. In terms of land claims, a highly controversial aspect is the future of natural conservation areas. Chellan and Khan (2008) illustrate that wildlife conservation in Africa has often competed with rural indigenous communities for land, water and forests. In many instances communities were forcefully removed from areas to make way for conservation areas. Many claims are on nature reserves or game parks where land invasions, which have often been associated with violence, have already occurred. Environmental and social conflicts have often emerged or been worsened by the slow pace of land restitution and redistribution.

\section{Managing land-related conflicts}

As there is no single definition of 'land' and property rights, there is also a wide range of land-related resources and uses, and so are there variations in approaches to the management of land-related conflicts. It is imperative that landscape planning activities, including those linked to land reform processes, take not only the physical facts of an area into consideration, but also deal with the social situation of the people whom the planning affects; that is through collaboration with local actors and stakeholders (Luz 2000; Wheeldon and 


\section{Land-related conflicts in Sub-Saharan Africa}

Faubert 2009). Spatial methods such as mental mapping help in building consensus and can form a base for resolving conflicts and differences of opinion. It also facilitates discussion on the basis of visual information presented. Wehrmann (2006:1) highlights the importance of reducing conflicts over land in Africa through the implementation of a functioning land registration and/or cadastral system which need to be supported by additional preventive measures such as conflict resolution (including moderation, mediation and arbitration), land management (focusing primarily on clarifying land rights and security of tenure) and psychotherapeutic approaches (for example, trauma counselling).

Communal land tenure will inevitably involve conflicts and disagreements between households and neighbourhoods. Disputes may be discussed and/or resolved in formal and informal institutions and practices. While experience with the implementation of the Communal Property Association in KwaZuluNatal clearly shows that linkages to, and support from broader institutions are essential, dispute resolution is also a key aspect of local autonomy and realising agency. Van der Waal's (2004) analysis of customary dispute mechanisms in Limpopo cautions against attempts to standardise rules. Similarly in communal land administration there are likely to be differences in the practices of particular communities - while these differences may appear insignificant to the outsider, they are expressions of local agency and autonomy that cannot be removed without undermining the collective action that is essential to manage common property resources.

The concept of human security and land security relates to concepts such as socio-ecological resilience and vulnerability as well as access to and control over land-related resources, especially security in terms of property rights. Folke et al. (2002:437) describe resilience of social-ecological systems as a combination of three characteristics:

- the magnitude of shock that the system can absorb and remain within a given state;

- the degree to which the system is capable of self-organisation; and

- the degree to which the system can build capacity for learning and adaptation. 


\section{Urmilla Bob}

In terms of land tenure systems and rights, these three aspects are clearly discernible. In Sub-Saharan Africa, there are constant shocks experienced in terms of climate change, collapse of socio-economic systems, ineffective land reform processes and persistent political unrest in many areas. In several of these contexts the magnitude is significant and can range from local to regional levels: as with the Mozambican floods, the civil unrest in Central Africa and the persistent droughts in Southern Africa. In terms of self-organisation, several national and local institutional structures are in a crisis. Additionally, as discussed earlier, there are numerous unresolved issues pertaining to traditional authority systems. These aspects further fuel land conflicts and contestations. Furthermore, it is imperative that land transformation processes consider the natural resource base. In particular, Wessels et al. (2003:157) state that land reform programmes in South Africa should refrain from promoting cultivation (and development) on marginal lands, especially in conflict areas with high biodiversity value. The above illustrates that in many instances, there is a lack of capacity to be resilient and cope with conflicts and shocks. These issues need to be addressed via appropriate policy development and implementation strategies.

It is imperative that community resilience in particular is enhanced. As the United States Agency for International Development (USAID 2006) illustrates, community resilience requires integrating and maintaining an optimal balance between community development (which provides the enabling governance and socio-economic and cultural conditions for resilience), disaster management (which focuses on preparedness, response, recovery and mitigation to reduce human and structural losses from disaster events) and land management (which establishes the environmental and natural resource conditions for resilience and ways of addressing issues with regard to the built environment). The following are specific benchmarks and elements to assess community resilience that is important for land management generally (adapted from USAID 2006:5):

Governance: Leadership, systems, and institutions provide enabling conditions for participatory management and community involvement with local government.

- Socio-economic and livelihood assets: Local economies are driven by sustainable and diverse livelihoods and healthy and peaceful socio-cultural conditions. 


\section{Land-related conflicts in Sub-Saharan Africa}

- Resources management: Active management of resources sustains environmental services and livelihoods and reduces risks from hazards.

- Land use management and structural design: Effective land use and structural design complement environment, economic and community goals and reduce risks from hazards.

- $\quad$ Risk knowledge: Community is knowledgeable about episodic and chronic hazards and measures to reduce risks.

- Warning and evacuation: Community is capable of receiving notifications and alerts of hazards, warning at-risk populations, and acting on alert.

- Emergency response: Emergency response institutions and systems are established and maintained to respond quickly to disasters and address emergency needs at the community level.

- Disaster recovery: Plans, systems, and institutions are in place to accelerate disaster recovery, actively engage communities in the recovery process and minimise negative environmental, social and economic impacts from disaster recovery.

Communities and countries in Sub-Saharan Africa generally do not perform well in relation to the above criteria.

In relation to managing land conflicts, the role of women's organisations is important to consider. For example, Campbell et al. (2000:344) show that while the role of women has not formally changed within the Maasai cultural system in Kenya, they have begun organising themselves into formal and informal groupings to improve their economic condition and access land. They assert that women are important land managers and through these groups they are challenging their marginalised economic and political status.

Huggins et al. (2005) and Theron (2009) also highlight the importance of reforming institutional (including policy) and judicial systems related to resolving land conflicts. This includes traditional mechanisms and recognises the importance of non-governmental organisations (NGOs). NGOs in particular can play a useful role as intermediaries in helping to resolve land-related conflicts. However, NGOs increasingly face a range of challenges including lack of human and financial resources. 


\section{Urmilla Bob}

\section{Conclusion}

The resolution of land-related conflicts is key to promoting sustainable development and attaining peace and security in Sub-Saharan Africa. Specifically, the article reveals that it is important to realise that land reform is essential for the empowerment of historically disadvantaged people and communities, and successful development more generally. Effective land reform can reduce conflicts and create stability and security in communities. However, land reform processes that are inadequately conceptualised and implemented can create land-related conflicts.

Clearly, there is a range of land conflicts that vary in terms of intensity, extent of their spatial impact, complexity and impact on different groups of people. The most prevalent of these conflicts relate to

- tenure rights and land security, specifically in relation to ineffective land reform processes and forced migrations leading to civil unrest and instability;

- access to resources (including contestations in relation to agricultural activities, mining and conservation areas);

- inheritance conflicts;

- and more recently, gender-based conflicts.

Land scarcity and unfair market practices exacerbate land-related conflicts. The effective management of land conflicts is required to ensure that long-term, sustainable solutions are found and that the quality of life of those most affected by these ongoing disputes is improved. 


\section{Land-related conflicts in Sub-Saharan Africa}

\section{Sources}

Andrew, J.S. 2003. Potential application of mediation to land use conflicts in small-scale mining. Journal of Cleaner Production, 11, pp. 117-130.

Barnett, J. and W.N. Adger 2007. Climate change, human security and violent conflict. Political Geography, 26, pp. 639-655.

Bob, U., K. Swart, B. Maharaj and P. Louw 2008. Nature, people and the environment: Overview of selected issues. Alternation, 15 (1), pp. 17-44.

Bob, U. and V. Moodley 2003. Globalisation, rural women and access to environmental resources in South Africa. Proceedings of the International Conference: Local land use strategies in a globalising world: Shaping sustainable social and natural environments, 21-23 August 2003, Institute of Geography, University of Copenhagen.

Bogale, A., M. Taeb and M. Endo 2006. Land ownership and conflicts over the use of resources: Implications for household vulnerability in eastern Ethiopia. Ecological Economics, 58, pp. 134-145.

Campbell, D.J., H. Gichohi, A. Mwangi and L. Chege 2000. Land use conflict in Kajaido District, Kenya. Land Use Policy, 17, pp. 337-348.

Carton, B. 2000. Blood from your children: The colonial origins of generational conflict in South Africa. Pietermaritzburg, University of Natal Press.

Chellan, N. and S. Khan 2008. Contesting ecotourism development in the iSimangaliso Wetland Park in KwaZulu-Natal. Alternation, 15 (1), pp. 268-289.

Cousins, T. and D. Hornby 2002. Leaping the fissures: Bridging the gap between paper and real practice in setting up common property institutions in land reform in South Africa. No 19 Occasional Paper Series, Land reform and Agrarian change in Southern Africa. PLAAS. School of Government, University of the Western Cape, Cape Town.

Cross, C. and M. Friedman 1997. Women and tenure: Marginality and the left hand power. In Meer, S. (ed) Women, land and authority: Perspectives from South Africa. Braamfontein, National Land Committee.

Deininger, K. and R. Castagnini 2006. Incidence and impact of land conflict in Uganda. Journal of Economic Behaviour and Organisation, 60 (3), pp. 321-345.

Folke, C.S., T. Carpenter, L. Elmqvist, C. Gunderson, S. Holling and B. Walker 2002. Resilience and sustainable development: Building adaptive capacity in a world of transformations. Ambio, 31, pp. 437-440.

Hilson, G. 2002. Land use competition between small- and large-scale miners: A case study of Ghana. Land Use Policy, 19, pp. 149-156.

Huggins, C., H. Musahara, P.M. Kamungi, J.S. Oketch and K. Vlassenroot 2005. Conflict in the Great Lakes Region - How is it linked with land and migration? ODI: Natural Resource Perspectives, 96, pp. 1-4.

Kagwanji, P. 2009. Ethnicity, land and conflict in Africa: The cases of Kenya, Uganda, Tanzania and Rwanda. Nairobi, Africa Policy Institute Working Paper Series. 


\section{Urmilla Bob}

Kinsey, B.H. 2004. Zimbabwe's land reform programme: Underinvestment in post-conflict transformation. World Development, 32 (10), pp. 1669-1696.

KZN [KwaZulu-Natal] Provincial Team 2002. Assessment of the Msikazi Communal Property Association. Unpublished report prepared for the Department of Land Affairs.

Luz, F. 2000. Participatory landscape ecology - a basis for acceptance and implementation. Landscape and Urban planning, 50, pp. 157-166.

Majeke, A.M.S. 2005. The role of traditional leaders in land tenure: The original legal and constitutional framework. Paper presented at the conference on Land tenure reforms and the evolving role of traditional leaders, 16-18 November 2005, in Durban, South Africa.

Mkhabela, T. 2006. Impact of land tenure systems on land conflicts: Swaziland - a country case study. Africanus, 36 (1), pp. 58-74.

Odgaard, R. 2006. Land rights and land conflicts in Africa: The Tanzania case. Copenhagen, Danish Institute for International Studies.

Peters, P.E. 2004. Inequality and social conflict over land in Africa. Journal of Agrarian Change, 4 (3), pp. 269-314.

Reuveny, R. 2007. Climate change-induced migration and violent conflict. Political Geography, 26, pp. 656-673.

Rugege, D., U. Bob, V. Moodley, S. Mtshali, O. Mutanga and A. Mthembu 2007. A literature review for the Baseline Survey on Communal Land Rights Act in KwaZulu-Natal. Submitted to the Department of Land Affairs, Pretoria.

Theron, J. 2009. Resolving land conflicts in Burundi. Conflict Trends, 1 (2009), pp. 3-10.

United States Agency for International Development (USAID) 2006. Coastal community resilience: A guide for planning and action to address Tsunami and other coastal hazards, US Indian Ocean Tsunami Warning System (IOTWS) Programme, Bangkok.

Van der Waal, C.S. 2004. Formal and informal dispute resolution in the Limpopo Province, South Africa. Anthropology Southern Africa, 27 (3 and 4), pp. 111-121.

Van Leeuwen, M. 2009. Crisis or continuity? Framing land disputes and local conflict resolution in Burundi. Land Use Policy, Article in Press. Available from: <www.elsevier.com/locate/ landusepol> [Accessed 15 January 2010].

Viljoen, M.F. 2006. Bridging the economic divide in South African agriculture by improving access to natural resources. Agrekon, 45 (1), pp. 1-16.

Wehrmann, B. 2006. Solving land conflict in Africa. Available from: <http://www. gim-international.com/issues/articles/id655-Solving_Land_Conflict_in_Africa.html> [Accessed 20 July 2008].

Wessels, K.J., B. Reyers, A.S. van Jaarsveld and M.C. Rutherford 2003. Identification of potential conflict areas between land transformation and biodiversity conservation in north-eastern South Africa. Agriculture, Ecosystems and Environment, 95, pp. 157-178.

Wheeldon, J. and J. Faubert 2009. Framing experience: Concept maps, mind maps, and data collection in qualitative research. International Journal of Qualitative Methods, 8, pp. 69-83. 